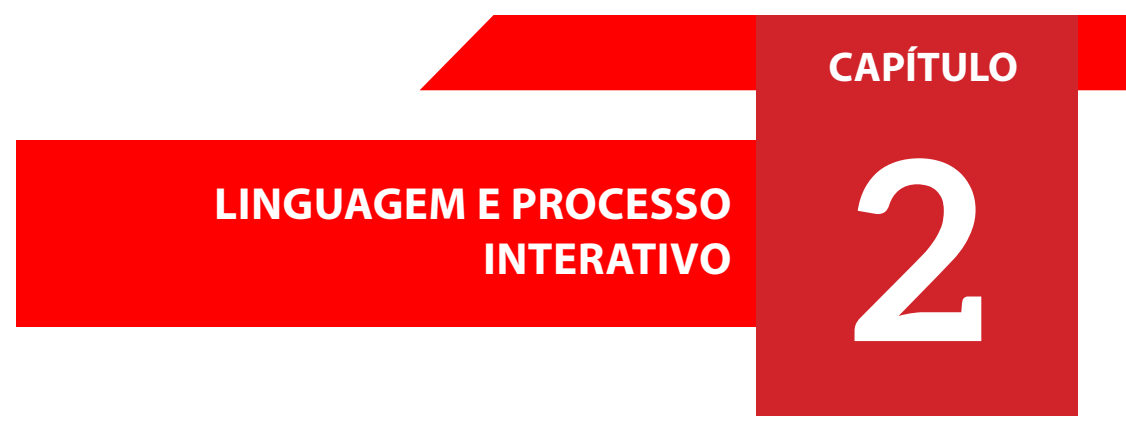

Uma das coisas mais fascinantes no nosso diaa-dia é o fato de contarmos uns aos outros o que vemos, ouvimos e sentimos, tendo a sensação de que os outros nos entendem, ou seja, que constroem percepções e experiências similares a nós. Essa atividade que parece tão natural e trivial permanece bastante misteriosa. A explicação caminha na direção das atividades linguísticas situadas e não das estruturas da língua descarnadas de seus usuários. Esse é o caminho vão do código à cognição e, neste percurso, tudo indica que o acontecimento seja um produto das interações sociais e não de uma mente isolada e individual (MARCHUSI, 2007).

O principal escopo deste capítulo é abordar a linguagem como prática social presente no discurso do sujeito imerso em um contexto amplo ou restrito. Como sistema de significados, a linguagem produz sentidos que o sujeito codifica e decodifica para entender o mundo e a sociedade onde está inserido. É por meio da linguagem que o homem manifesta suas ideias, opiniões e valores, ideologias, revela seu ethos e realça as paixões que considera importantes para pensar e organizar sua vida em sociedade e se constituir como sujeito social. É por meio da linguagem que o homem se faz sujeito do discurso. Língua e linguagem, ainda que intimamente ligadas uma a outra, possuem conceitos específicos. 
A língua, do ponto de vista semântico, é um instrumento de comunicação composta por regras gramaticais (sintaxe, morfologia, fonologia, concordância, regência, entre outras) que possibilitam que determinado grupo de falantes consiga produzir enunciados que lhes permita comunicar-se e compreender-se. É usada por um povo, por uma nação, e o conjunto de regras da sua gramática socializadas, não permite, de um modo geral, que alguém seja "uma ilha", isto é, que viva isolado do processo de comunicação entre os falantes.

A linguagem pode ser definida qualquer meio sistemático de comunicar ideias ou sentimentos por meio de signos convencionais, sonoros, gráficos, gestuais etc. É por meio da linguagem que os falantes expressam suas ideias, pensamentos, sentimentos, emoções e ações pessoais e é por intermédio dela que se dá o processo interativo entre duas pessoas, seja pela fala, seja pela escrita - representação simbólica da fala -, em situações reais de comunicação e expressão no meio social. É impossível a fala, o discurso que se faz por meio da linguagem, sem a participação do instrumento criado e fornecido pela coletividade - a língua -, uso coletivo da linguagem que se constitui de palavras.

A linguagem tem sido interpretada ao longo da História de maneira diversificada, porém destacam-se, nos estudos linguísticos, três formas que a sintetizam: em primeiro lugar, é vista como uma representação do pensamento (aquilo que é trazido à existência por meio da atividade intelectual). Depois, é concebida como uma ferramenta de comunicação (processo de emissão e recepção de mensagens por meio de métodos e/ou sistemas convencionados, como as TIC, por exemplo). Em terceiro lugar, a linguagem é concebida como forma de ação ou interação. Para Koch $(2015$, p. 7),

A mais antiga dessas concepções é, sem dúvida, a primeira, embora continue tendo seus defensores na atualidade. Segundo ela, o homem representa para si o mundo através da 
linguagem e, assim sendo, a função da língua

é representar (= refletir) seu pensamento

e seu conhecimento de mundo. A segunda concepção considera a língua como um código através do qual um emissor comunica a um receptor determinadas mensagens. A principal função da linguagem é, neste caso, a transmissão de informações. A terceira concepção, finalmente, é aquela que encara a linguagem como atividade, como forma de ação, ação interindividual finalisticamente orientada; como lugar de interação que possibilita aos membros de uma sociedade a prática dos mais diversos tipos de atos, que vão exigir dos semelhantes reações e/ou comportamentos, levando ao estabelecimento de vínculos e compromissos anteriormente inexistentes.

Como é possível observar, a linguagem é concebida como mecanismo de atividade, de ação, como lugar de interação expressa por diversas maneiras no ato da fala e que exige dos interlocutores o estabelecimento de um liame moral. Assim, a linguagem é vista como prática de interação entre dois sujeitos e pressupõe uma ação mútua entre o ethos, o orador na ação discursiva, e o pathos, o auditório, o ouvinte na enunciação discursiva. Da mesma forma, na $\mathrm{EaD}$, a atuação recíproca ocorre entre a instituição cedente e controladora do curso e/ou disciplina e o aluno desfruta dos serviços oferecidos nos ambientes virtuais de aprendizagem por meio das TIC.

A linguagem concebida como uma ação intersubjetiva liga-se tanto à "teoria da enunciação" quanto à "teoria dos atos da fala". Quando se fala a respeito dos atos da fala, fica subentendido que o ato de falar de um locutor é sempre dirigido a um ouvinte e a fim de que a fala atinja seus objetivos é necessário que o interlocutor 
seja capaz de captar sua intenção. Na enunciação se pressupõe um locutor e um ouvinte, de modo que o locutor, o "eu" discursivo, tende de alguma forma a influenciar o outro, o "tu"; já a teoria dos atos da fala, que surgiu no interior da filosofia da linguagem, entende a linguagem como forma de ação, que faz refletir sobre as diversas formas de ações humanas que se realizam por meio da linguagem (KOCH, 2015).

A teoria dos atos da fala entende que a eficiência e o pragmatismo linguístico implicam, por exemplo, muito mais do que a simples emissão de um enunciado. Assim, na frase "Eu | te | adoro", não basta apenas o entendimento de sua estrutura sintática (eu=sujeito, te=objeto, adoro=verbo transitivo) para a compreensão do ato locucionário (conjunto de sons organizados de acordo com as regras da língua); é necessário levar em conta o contexto situacional em que a frase foi dita, da entoação, da acentuação, intencionalidade, entre outros atos. Para Koch (2015, p. 11-12),

\begin{abstract}
A Teoria da Enunciação tem como postulado básico que não basta ao linguista preocupado com questões de sentido descrever os enunciados efetivamente produzidos pelos falantes de uma língua: é preciso levar em conta, simultaneamente, a enunciação ou seja, o evento único e jamais repetido de produção do enunciado. Isso porque as condições de produção (tempo, lugar, papéis representados pelos interlocutores, imagens recíprocas, relações sociais, objetivos visados na interlocução) são constitutivas do sentido do enunciado: a enunciação vai determinar a que título aquilo que se diz é dito.
\end{abstract}

Como se pode depreender da citação de Koch (2015), para que haja o pleno entendimento de um enunciado linguístico, 
faz-se necessário, segundo a teoria dos atos da fala, não apenas conhecer a frase, por exemplo, no seu nível sintático, ou seja, de sua função dentro do período oracional, mas ter domínio sobre outras variáveis. Dentre essas variáveis, segundo Barros (1990), há a intencionalidade (o que se pretende com) da enunciação, a situacionalidade (sob quais circunstâncias), a aceitabilidade (a quem é dirigido, público-alvo), informatividade (adequação da linguagem à situação sociocomunicativa, ao que está sendo dito), o quando, o onde e o lugar em que ocorre sua efetivação, conhecimentos extralinguísticos e enciclopédicos, além, é claro, sobretudo, da intenção discursiva do interlocutor.

Quando uma mulher, no processo de enunciação discursivo, diz a outra, por exemplo, "Hoje, mulher só pensa em sacanagem", a frase está muito longe de significar apenas o que está no plano da superfície. Na frase em questão, embora seja utilizado um advérbio de tempo (hoje) como indicativo de um tempo presente que se refere ao "aqui e agora", nas entrelinhas fica subentendido que esta circunstância de tempo presente remete, quando de sua interpretação ou decodificação, ao passado. Se a enunciação exterioriza "Hoje, mulher só pensa em sacanagem", permite, numa conjectura, inferir, por meio de um raciocínio de causa/efeito que no passado, esta mesma mulher (no imaginário extralinguístico e enciclopédico do falante) não pensava só em sacanagem, mas em virtudes, tais como criar os filhos, ser uma boa dona de casa etc. Ainda que este imaginário subjacente ao falante seja apenas conjectura, pode e tem grande possibilidade de se constituir como uma realidade no plano da análise do discurso.

Em outras palavras: no enunciado em questão, uma formação discursiva indicativa de um presente circunstancial (hoje) remete, linguisticamente, a um tempo passado e esta observação permite afirmar, do ponto de vista da linguagem, que o discurso, dependendo de sua intencionalidade ou situacionalidade, por exemplo, tem um sentido presente e um sentido ausente e o falante 
só consegue interpretar melhor estes atos da fala quando põe em funcionamento seu conhecimento de mundo, seu conhecimento linguístico, seu conhecimento enciclopédico e extralinguístico. Enfim, como bem salienta Barros (1990, p. 54),

\begin{abstract}
Partindo do princípio de que todo discurso procura persuadir seu destinatário de que é verdadeiro (ou falso), os mecanismos discursivos têm, em última análise, por finalidade criar a ilusão de verdade. Há dois efeitos básicos produzidos pelos discursos com a finalidade de convencerem de sua verdade, são o de proximidade ou distanciamento da enunciação e o de realidade ou referente.
\end{abstract}

\title{
2.1 Ethos
}

Em verbete de dicionário, ethos significa conjunto dos costumes e hábitos fundamentais, no âmbito do comportamento (instituições, afazeres etc.) e da cultura (valores, ideias ou opiniões e valores), característicos de uma determinada coletividade, época ou região. Visto sob esta perspectiva, o ethos está presente na vida de cada cidadão ou cidadã que habita uma determinada nação, uma vez que tudo o que se pensa, tudo o que se sente e todo seu agir ocorre por intermédio de um conjunto de instituições ou convenções sociais que se sustentam em um ideal normalmente de caráter coletivo. Na perspectiva aristotélica, ethos tem um sentido 
mais restrito e diz respeito ao caráter que o orador ${ }^{6}$ demonstra ter diante de um auditório.

Desse modo, os acordos sociais institucionalizados, que se manifestam no uso da língua como instrumento de comunicação e interação, são feitos para uso coletivo do grupo de pessoas e sua principal intenção é funcionar como uma prática social no discurso dos indivíduos. O ethos (estudo do caráter), aplicado ao campo do comportamento humano, pode ser entendido, então, como algo externo e, segundo a Psicanálise, da ordem do Superego ${ }^{7}$, isto é, das instituições externas controladoras do desejo humano. Nesse enfoque, se enquadra a família, o Estado, a religião, a escola como elemento externo que tem a função, enquanto ethos, de gerar um discurso dirigido ao interlocutor.

Os alunos de EaD, como qualquer falante, encontram-se num momento singular de seu percurso vivencial: inserem-se numa prática social em construção, vigiada e controlada pelas macro e microinstituições. Assim, a constituição da verdade para

6. "O que é um orador? É alguém que deve ser capaz de responder às perguntas que suscitam debate e que são aquilo sobre o que negociamos. Essa capacidade é um saber específico: o médico dever responder às perguntas médicas, o advogado às perguntas jurídicas e assim por diante. Espera-se que eles respondam bem, pois estudaram para tal; quando quem se expressa não é nem advogado nem médico, mas simplesmente um ser humano, seu 'saber específico' refere-se a poder responder bem enquanto homem, sua virtude não está sendo mais a de um especialista, mas a virtude em geral, um ethos compartilhado por todos, em que cada um deve poder se reconhecer, e ao qual pode se identificar" (MEYER, 2007, p. 34).

7. "Uma das instâncias da personalidade tal como Freud $\left({ }^{*}\right)$ a descreveu no quadro de sua segunda teoria do aparelho psíquico: o seu papel é assimilável ao de um juiz ou de um censor relativamente ao Ego. Freud $\left({ }^{*}\right)$ vê na consciência moral, na auto-observação, na formação dos ideais, funções do Superego" (LAPLANCHE \& PONTALIS, 2001, p. 497).

(*)FREUD, Sigmund. Das Ich und das Es, 1923. G.W, XIII, 282; S.E. XIX, 52-3.

$\left.{ }^{*}\right)$ FREUD, Sigmund. Neue Folge der Vorlesungen zur Einführunf in die

Psychoanalyse, 1932, GW, XV, 138; S.E. XXII, 129. 
um auditório sofre influência de todos esses fatores externos. A análise, portanto, centrada no discurso dos sujeitos da pesquisa, irá perscrutar o dito e o não-dito, mas inteligível no processo de constituição das respostas dadas para o inventário de opiniões e valores e nos relatos solicitados.

0 discurso infiltra-se na ordem da internalização, do recebimento, da introjeção e apreensão dos afazeres e desvela a recepção e aceitação de tudo aquilo que é da ordem da assimilação. $O$ ethos, aplicado ao problema da EaD, revela que está em ação uma fala do sujeito do discurso, ou seja, a figura do orador, que, como figura de autoridade ou autorizada, deve demonstrar credibilidade, confiança e, sobretudo, caráter íntegro para a persuasão do interlocutor -0 auditório, simbolizado pelo pathos.

Partindo do pressuposto de que em análise do discurso o ethos refere-se à figura do orador, nos cursos de EaD, que se utilizam das TIC por meio do AVA, a instituição cedente do curso ou disciplina, representada pelos professores e pelos monitores, assume o ethos discursivo (corresponde a caráter do orador) porque é a partir de sua voz, de seu discurso dirigido ao interlocutor, que se efetivará a interação entre o "eu" - instituição realizadora do curso - e o "tu" - aluno que compra os serviços oferecidos pela instituição educacional. Quando o aluno se manifesta, a situação se inverte, muda-se o turno: o aluno, agora orador, ocupa um lugar social e fala a partir desse lugar, em circunstância determinada, com limites que são impostos por fatores contextuais muito específicos.

Todo discurso proferido pelo orador supõe que haja um interlocutor para ouvir a sua palavra e todo discurso expresso pela palavra, de uma forma ou de outra, visa atingir os valores, as opiniões e valores e as paixões (pathos) dos outros. Para que haja a internalização do ethos do orador no auditório, é necessário que a palavra revele sua potencialidade persuasiva, que suscite paixões no "tu". Nesse contexto, ressaltam-se as paixões que, segundo 
Aristóteles (2000, p. XL) não possuem, como elemento afetivo, "nem meios nem fins, as paixões são as respostas às representações que os outros concebem de nós, são representações em segundo grau".

As paixões, ainda segundo Aristóteles (2000), constituem um teclado no qual o orador toca com a intenção de convencer, mover pela razão, pela exposição de provas lógicas, de persuadir, isto é, mover pelo coração, pela exposição do lado emocional, de sorte que as paixões reflitam, no fundo, as representações que fazemos dos outros, considerando-se o que eles são para nós, realmente ou no domínio de nossa imaginação. Ferreira (2010) refere-se, didaticamente, a "convencer" como um ato de expor provas lógicas com o intuito de mover pela razão. Persuadir, para esse autor (op. cit., 2010), é investir num discurso que explora o lado emocional, que pretende mover pelo coração.

Pode-se dizer, sob esta perspectiva, então, que o movimento retórico aristotélico, para a explicação e elucidação do ethos, no tocante à persuasão, é obtida quando o discurso é proferido de maneira a deixar no auditório (pathos) a impressão de que o caráter do orador o torna digno de fé, confiança e credibilidade. A objetividade do discurso do orador, sobretudo, a sua capacidade de persuadir, deve ser capaz de influenciar a tomada de decisões do auditório.

Essa posição dicotômica é também interessante para nossos propósitos de pesquisa, pois o exterior do estudante de EaD é analisado por muitos especialistas ligados à área da Educação, da Sociologia, da Psicologia e de áreas afins. 0 exterior/interior, amalgamados no discurso, ainda merece um debruçar mais atento. $\mathrm{O}$ dizer dos sujeitos pode revelar nuances de racionalidade e consciência do processo de condução da formação e, simultaneamente, as pulsões interiores que movimentam o estar no mundo, daquela forma, naquele instante. 
Oethos-imagem do orador-se constróipor meio da linguagem que pode ser expressa de modo a influenciar o interlocutor e, sob esta perspectiva, ela pode ser usada para a manipulação do auditório (Platão ${ }^{8}$ ), para se expressar bem enquanto a arte das palavras (Quintiliano ${ }^{9}$ ), e exposição de argumentos com a intenção de persuadir alguém (Aristóteles ${ }^{10}$ ). Fazendo um recorte no ethos e delimitando-o como uma paixão interior, Meyer (2007, p. 34), em A Retórica, afirma que

Para os gregos, o ethos é a imagem de si, a personalidade, os traços de comportamento, a escolha de vida e dos fins (daí a palavra "ética"). 0 ethos é uma excelência que não tem objeto próprio, mas se liga à pessoa, à imagem que o orador passa de si mesmo, e que o torna exemplar aos olhos do auditório, que então se dispõe a ouvi-lo e segui-lo.

Nesse contexto, o orador como princípio de uma autoridade, de uma ética, de uma moralidade, é também, um domínio, um nível, uma estrutura, uma dimensão; enfim, o ethos - como a imagem do orador - pressupõe alguém com quem o auditório (pathos) se identifica e deposita credibilidade e confiança na palavra proferida. Do ponto de vista da escola psicanalítica junguiana, o ethos é denominado arquétipo ${ }^{11}$ da persona, isto é, a imagem com que as pessoas (todos nós, sem exceção alguma) se apresentam para o

8. Platão (427 a.C. - 347 a.C.) apud Meyer (2007)

9. Quintiliano (1865) apud Meyer (2007).

10. Aristóteles (1991) apud Meyer (2007).

11. "Arquétipo é uma espécie de aptidão para reproduzir constantemente as mesmas ideias míticas; se não as mesmas, pelo menos parecidas. Parece, portanto, que aquilo que se impregna no inconsciente é exclusivamente a ideia da fantasia subjetiva provocada pelo processo físico. Logo, é possível supor que os arquétipos sejam impressões gravadas pela repetição de reações subjetivas" (JUNG, 2008, p. 61). 
outro, sendo este outro, o "tu", isto é, a segunda pessoa do status discursivo. Neste Livro, a concepção do ethos assume o caráter da argumentação centrada na pessoa do orador (representado aqui pela instituição que oferece o curso de EaD), a fim de ele possa influenciar e persuadir o auditório (os alunos).

Sob qualquer perspectiva científica, o ethos se ressalta como um elemento fundamental para a compreensão do con-siderare (como agir, pensar, encontrar o rumo, verificar a utilidade prática e física do existir e do destino que se constrói) e do de-siderare (examinar com respeito e cuidado, sentir a falta de algo, buscar) de cada um dos sujeitos da pesquisa, evidentemente, nos limites e extensões das questões propostas para análise (BORDELOIS, 2007).

Sempre que se fala a respeito do orador, vem logo à mente a figura de uma pessoa que se propõe a discursar para uma plateia ou auditório a respeito de um determinado assunto ou tema e normalmente estes assuntos ou temas visam provocar no ouvinte, no mínimo, algumas reflexões em torno daquilo que está sendo proferido por meio da discursividade do orador. A discursividade dos sujeitos da pesquisa pode contribuir para o entendimento do "desejar vivamente" (ou não) os efeitos que a EaD poderá produzir em cada um e em todos quando vistos em um contexto mais amplo, que envolve o próprio indivíduo, as instituições e as oportunidades programáticas ligadas ao "estar formado". Quando se fala que o mínimo que o orador espera de um auditório diante de sua argumentação é a reflexão, isso não constitui nenhum exagero, no sentido lato da expressão do termo, pois, realmente, após a exposição de determinado assunto, o auditório, representado pelos ouvintes, pode pôr-se a aprovar ou desaprovar, por meio da reflexão, tudo aquilo que foi dito ou o que é pior: tudo aquilo que não foi dito e que se esperava que se dissesse. A análise aqui demonstrada no Capítulo 2 não pretende, a priori, imprimir juízo de valores. Por outro lado, procura, sim, encontrar os valores de cada um dos entrevistados para, depois, ainda que modestamente, demonstrar 
um painel de paixões e opiniões e valores que perpassam o interior/ exterior do aluno que se submete ao ensino a distância, neste momento, nesta conjuntura, neste país: breve instantâneo de uma história que ainda se constrói.

Sabemos que, diferentemente do que a maioria das pessoas pensa, nem tudo o que o orador diz corresponde às expectativas do ouvinte, mesmo que o orador possua, interiormente, a crença virtuosa de que ele tem o poder de influenciar e, sobretudo, persuadir e convencer os outros pelo seu ato retórico discursivo, nem sempre o discurso corresponde ao anseio do auditório. Quando a instituição que forma se impõe discursivamente sobre o viver do aluno, supõe satisfazer, propiciar o desejo do auditório. É importante, porém, ressaltar que os desejos e compromissos são unilaterais. 0 acordo é fundamental entre orador e auditório e isso implica negociação de distâncias entre os sujeitos. Por isso, quando fala, o orador, por meio de sua palavra, coloca em jogo seu ethos que deveria, antes de tudo, pretender uma aproximação com o auditório numa relação entre o "eu" e o "tu" porque,

O orador, o auditório e a linguagem são igualmente essenciais. Isso não significa que $o$ orador e o auditório negociam sua diferença, ou sua distância, se preferirmos, comunicando-a reciprocamente. $O$ que constitui a sua diferença, e mesmo o seu diferencial, é certamente múltiplo, e pode ser social, político, ético, ideológico, intelectual - e sabe lá o que mais -, mas uma coisa é certa: se não houvesse um problema, uma pergunta que os separasse, não haveria debate entre eles, nem mesmo uma discussão. (MEYER, 2007, p. 25)

Por fim, o orador, na edificação de seu discurso, como se já disse, edifica, da mesma forma, uma imagem de si mesmo e, segundo Aristóteles (2000) esta imagem (ethos) deve, persuasiva e 
convincentemente, se preocupar em inspirar confiança no ouvinte, de modo que esta confiança seja o resultado da força discursiva do orador. $\mathrm{O}$ ethos é uma imagem do orador, não se constitui da imagem real, mas, sim, da imagem discursiva, um autor implícito que passa confiança, mas, afinal de contas, quais são as razões que fazem com que se deposite confiança no ethos - na figura do orador? Para Aristóteles (2000, p. 53),

Há três coisas que inspiram confiança no orador, porque há três razões que nos levam à convicção, independentemente das de demonstrações. São o bom senso, a prudência, a sabedoria prática (phrónesis), a virtude (areté) e benevolência (eúnoia). Os oradores podem afastar-se da verdade por todas essas razões ou por uma dentre elas. Por causa da falta de bom senso, podem não exprimir uma opinião correta; por causa de sua malvadeza podem, mesmo pensando bem, não expressar aquilo que pensam; mesmo sendo prudentes e honestos, podem não ser benevolentes. Por estas razões os oradores podem, mesmo conhecendo a melhor solução, não aconselhála. Não há nenhum outro caso.

Além da sabedoria prática (phronesis), da virtude (Areté) e da benevolência (eúnoia), o ethos discursivo assenta-se, também, na honorabilidade e na confiança que nele se deposita; daí, dizer-se, então, que o papel do orador, ethos, é determinante na retórica.

\subsection{Pathos - uma paixão aristotélica}

Qualquer indivíduo, em sã consciência, há de concordar com a afirmação de que ninguém faz quase nada na vida se não for motivado por uma grande paixão - sentimento ou emoção levado a 
um alto grau de intensidade -, de forma que a força motivacional se encontra dentro do sujeito. É ali que se manifestam as mais variadas formas de paixão de que se tem notícia: a paixão amorosa, a paixão pelo trabalho, a paixão pela causa alheia, a paixão pela ética, a paixão pela liberdade de expressão, a paixão pela solidariedade e integridade humana, a paixão pela religiosidade ou não, a paixão por algum tipo de desejo; enfim, a paixão pelo ensino e pela aprendizagem como alternativa para se tornar uma pessoa melhor social e culturalmente falando no processo de interatividade com seus semelhantes na comunidade de falantes.

Falar em paixão implica sempre uma reciprocidade, visto que é no jogo das relações sociais que o indivíduo dá vida à sua paixão e aos seus desejos. Visto sob esta perspectiva, "as paixões refletem, no fundo, as representações que fazemos dos outros, considerandose o que eles são para nós, realmente ou no domínio de nossa imaginação. Poder-se-ia então dizer que há aí um jogo de imagens, talvez mesmo de imagens recíprocas, antes que a fonte das reações morais, cujo objetivo seria então o da Ética" (ARISTÓTELES, 2000, p. $\mathrm{XLI})$.

As paixões que estão dentro do sujeito se manifestam por meio de opiniões, valores e opiniões. Para que estas opiniões e valores sejam acatados pelo sujeito se faz necessário que ele seja convencido, persuadido a realizar aquilo que lhe causa paixão. É preciso apresentar-lhe os prós e os contras, mas ele não é um sujeito isolado, tem o direito de optar por aquilo que julga melhor, e, para isso precisa ser convencido ou persuadido emocional e racionalmente.

Para convencer ou persuadir, é necessário que haja argumentação e esta mesma argumentação deve ser edificada pelo logos (uma proposição discursiva baseada em um raciocínio lógico sedimentado em premissas e conclusões), pelo conjunto de estratégias e raciocínios retóricos (indução, dedução, silogismos, entre outros). 
Se o ethosse refereà figura do orador-sujeito que deveser digno de confiança quando se refere ao ato de influenciar no ouvinte -, "o pathos, um argumento (lembramos que argumentar é apresentar razões que justificam ou refutam um determinado ponto de vista) de natureza psicológica, está vinculado à afetividade ${ }^{12}$, remete ao auditório, ao conjunto de emoções, a paixões, sentimentos que o orador consegue despertar no ouvinte" (FERREIRA, 2010, p. 103).

$\mathrm{E}$ na $\mathrm{EaD}$, como se promove o pathos? Como foi dito na Introdução, a aprendizagem na modalidade a distância acontece em salas virtuais, espaço de interação entre tutor e aluno, em que o principal objetivo é tirar as dúvidas e construir o conhecimento, pois pressupõe que o aluno tenha lido os textos, visto os vídeos das aulas e demais atividades propostas. Todavia, cabe aqui uma pergunta de condição sine qua non: Quais estratégias devem o professor e o tutor utilizar para despertar o interesse do aluno pelo curso ou disciplina oferecidos pela instituição cedente? Partindo-se do pressuposto de que o professor e/ou tutor, na actio, representa o ethos e que o aluno significa o pathos, isto é o auditório, fica evidente que se "o ethos remete às respostas, o pathos é fonte das questões e estas respondem a interesses múltiplos, dos quais dão prova as paixões, as emoções, ou simplesmente as opiniões". (MEYER, 2017, p. 36).

Já que no processo discursivo entre os interlocutores estão em jogo o ethos e o pathos, fica fácil perceber que aquele, concebido

12. “É possível ganhar as pessoas para nós por meio do exercício e prática da afetividade? Sem dúvida que sim. 0 pai ganha o filho cem por cento quando o trata com afeição e carinho, a dona de casa suporta os piores vícios e insanidades do esposo quando ele a reveste de uma atmosfera de afetividade. 0 ladrão inconsequente, frio e calculista se rende perante um ato da afetividade por parte da vítima de um assalto e a jovem apaixonada e enamorada suporta até a traição do namorado paquerador quando este, em seus momentos de intimidade com a namorada traída, a acalenta com afetividade e com gestos de carinho. 0 aluno arrogante e autoritário sucumbe ante as palavras calmas, tranquilas e afetuosas do professor tolerante" (OLIVEIRA, L., 2014, p. 19). 
como orador, deve levar em consideração as paixões porque os questionamentos e/ou paixões expressam a subjetividade de um problema. Além disso,

As paixões humanas, sabemos, funcionam tanto para unir quanto para separar as pessoas. Se o amor une, o ciúme separa. Se a dor congrega, se o respeito consolida amizades, a inveja e a impudência separam. Como nem todos reagem da mesma forma às mesmas paixões, o estudo da identidade do auditório é fundamental em retórica. (FERREIRA, 2010, p. 103)

Por isso, as instituições que promovem EaD estão sempre atentas aos reflexos externos do ato de ensinar. São muitos e intrincados os efeitos patêmicos. Fiorin (2015, p. 223), por exemplo, apresenta o pathos sob outro ponto de vista, ainda que esteja ligado diretamente às paixões do auditório. Para esse estudioso da linguagem, pathos "são aqueles argumentos que fazem apelo às paixões do auditório: argumentum ad populum, argumentum ad misericordiam, argumentum ad baculum (argumento que faz apelo ao povo, argumento que faz apelo à piedade, argumento que faz apelo ao porrete)".

O argumentum ad populum é mais eficiente quando não apela de maneira explícita para certas conclusões, mas apenas as sugere a partir de afirmações e perguntas enfáticas; já o argumentum ad misericordiam é aquele que apela para a piedade ao mostrar alguém como digno de pena, porém, explorando sentimentos de culpa ou simpatia por uma causa; por fim, o argumentum ad baculum apela para a força, ele força o orador a aceitar sua proposta por meio de uma ameaça, uma proibição, enfim, a um valor negativo. 
Nem todos esses argumentos são explicitamente utilizados no caminho das instituições que promovem EaD, mas, sem dúvida, em vários momentos do percurso o monitor, instaurado como representante da instituição, se vale desses recursos para manter o aluno motivado pelo curso e pelo destino que traçou para si mesmo no ato da matrícula. Há um grau de passionalidade centrado num estado de alegria que é muito necessário tanto na EaD quanto em qualquer outra modalidade de curso de formação de pessoas.

Pode parecer curioso considerar a alegria como uma paixão, pois, normalmente, não se encontra no inventário canônico das paixões eufóricas ou disfóricas. Como afirma Bordelois (2007), do ponto de vista etimológico, alegria tem relação com ideias de agilidade, velocidade e vivacidade. Na percepção atual do termo, a alacritas latina faz sobressair a ideia de dinamicidade e animação. Esses elementos intrínsecos que mantêm ou não um aluno no curso determinam seu comportamento estudantil. Tanto as instituições precisam tornar felizes seus estudantes quanto o próprio aluno precisa manter em si essa espécie de chama interior que o impulsiona. A manutenção do estado de alegria implica opiniões e valores, valores e energia. Todos esses elementos interessam para os propósitos deste Livro porque eles contribuem para o processo de interdiscursividade e também para o sociointerarionismo.

A teoria sociointeracionista de Vygotsky (1994) parte do pressuposto de que o desenvolvimento do homem se dá a partir de uma perspectiva sociocultural. Com isso ele quer dizer que o ser humano se constitui na interação com o meio social em que ele está inserido. Além disso, acredita, da mesma forma, que o processo de interação entre o sujeito e o meio social se efetiva a partir de uma relação dialética, uma vez que ele não só internaliza as formas culturais mas também intervém e as transforma de acordo com a sua necessidade. 
$\mathrm{Na}$ configuração do sociointeracionismo, para Vygotsky (1994), está presente linguagem e pensamento, uma vez que o desenvolvimento da linguagem implica o desenvolvimento do pensamento, pois pelas palavras o pensamento ganha existência. Visto sob este enfoque, é possível afirmar que a linguagem tem uma função muito importante na medida em que ela é a responsável pela estruturação do pensamento e, sem dúvida, é ferramenta básica para a construção de conhecimentos. 